\title{
Correction to: Peritoneal Metastases in Colorectal Cancer
}

Richard Jacobson, MD ${ }^{1,2}$, Scott K. Sherman, MD ${ }^{1}$, Fadi Dahdaleh, MD ${ }^{1}$, and Kiran K. Turaga, MD, MPH ${ }^{1}$

${ }^{1}$ Department of Surgery, University of Chicago, Chicago, IL; ${ }^{2}$ Department of Surgery, Rush University Medical Center, Chicago, IL

CORRECTION TO: ANN SURG ONCOL (2018) 25:2145-2151

HTTPS://DOI.ORG/10.1245/S10434-018-6490-X

In the original article Fadi Dahdaleh's last name was spelled incorrectly. It is correct as reflected here.

The original article can be found online at https://doi.org/10.1245/ s10434-018-6490-x.

(C) Society of Surgical Oncology 2019

Published Online: 16 January 2019

K. K. Turaga, MD, MPH

e-mail:kturaga@surgery.bsd.uchicago.edu 